\title{
PENINGKATAN EFEKTIVITAS PEMBELAJARAN PENDIDIKAN AGAMA ISLAM (PAI) MELALUI MANAJEMEN KELAS
}

\author{
Oleh: \\ Romdloni \\ Dosen STKIP Nurul Huda OKU Timur Sumatera Selatan \\ romdloni29@gmail.com
}

\begin{abstract}
Abstrak
Sistem desentralisasi pendidikan di era sekarang ini memberikan peluang kepada setiap lembaga sekolah untuk meningkatkan kualitas mutu sekolah yaitu dengan mengimplementasikan Manajemen Berbasis Sekolah (MBS). Konsep Manajemen Kelas ini berusaha untuk memberikan penyelesaian terhadap masalah di kelas, yang cakupannya tidak hanya terbatas pada penyampaian materi, akan tetapi mencakup beberapa hal yang menyeluruh untuk mengorganisasi kelas antara lain: pertama kegiatan akademik berupa perencanaan, pelaksanaan dan penilaian pembelajaran. Kedua kegiatan administratif yang mencakup kegiatan procedural dan organisasional seperti penataan ruangan, pengelompokan siswa dalam pembagian tugas, penegakan disiplin kelas, pengadaan tes, pengorganisasian kelas, pelaporan. Jadi konsep manajemen kelas adalah berusaha memberdayakan potensi kelas yang ada seoptimal mungkin untuk mendukung proses interaksi edukatif dalam mencapai tujuan pembelajaran yang efektif khususnya dalam materi PAI.

Kata Kunci : Efektifitas Pembelajaran, PAl, Manajemen Kelas.
\end{abstract}

\section{A. PENDAHULUAN}

Belajar adalah suatu proses yang komplek dan terjadi pada setiap orang sepanjang hidupnya. Proses belajar itu terjadi karena interaksi antara seseorang dan lingkungannya. Oleh karena itu belajar dapat terjadi kapan dan dimana saja. Adapun secara sederhana belajar dapat diartikan sebagai suatu proses yang terjadi karena adanya usaha untuk mengadakan perubahan terhadap diri manusia yang melakukan, dengan maksud memperoleh perubahan dalam dirinya pada tingkat pengetahuan, ketrampilan dan sikap serta selalu ada usaha berupa latihan. ${ }^{1}$

${ }^{1}$ Suharsimi Arikunto, Manajemen Pengajaran Secara Manusiawi (Jakarta : PT. Rineka Cipta, 1990), hlm. 19 
Proses belajar mengajar yang diselenggarakan di beberapa sekolah sebagai pusat pendidikan formal lebih dimaksudkan untuk mengarahkan perubahan pada diri sendiri secara terencana baik dari segi kognitif, afektif dan psikomotorik. Dalam interaksi belajar tersebut sangat dipengaruhi oleh beberapa komponen yang antara lain terdiri atas: murid, guru, kepala sekolah, materi pelajaran, sarana prasarana (perpustakaan), lingkungan dan beberapa fasilitas lain yang memenuhi dalam proses pembelajaran sehingga akan menunjang keefektifan proses pembelajaran.

Peranan guru sangat penting dalam pendidikan. Baik buruknya pendidikan dipengaruhi bagaimana seorang guru bisa memanifestasikan dan mengaplikasikan sumbangsihnya ke dalam lembaga formal untuk mewujudkan kecerdasan bangsa dan cita-cita negara, sehingga antara guru dan pendidikan merupakan satu komponen yang tidak bisa dipisahkan. Jika dari kata "pendidikan" berarti ada pendidik dan ada yang dididik, maka artinya guru dan murid. Seorang guru atau pendidik bekerja sesuai dengan kurikulum sekolah, baik pada tingkat SD, SMP, SMU. Karena itu, frekuensi pendidikan di dalam lembaga pendidikan diharapkan mampu menghasilkan anak didik yang bisa menyelesaikan pendidikannya sesuai target yang telah ditentukan, dengan mengacu pada kurikulum yang dijadikan sebagai program pembelajaran. Jika interaksi antara kurikulum yang diajarkan oleh guru dengan kemampuan murid dalam menyerap materi itu menjadi satu kesatuan yang utuh, maka target maksimal akan tercapai secara seimbang.

Dalam kenyataannya yang ada di lapangan mata pelajaran Pendidikan Agama Islam dewasa ini mutunya masih rentan karena belum mencapai target yang diinginkan secara memadai khususnya di sekolah umum. Selain realitas tersebut, ada asumsi bahwa "Dalam kehidupan sekolah sering kita lihat adanya para guru yang dapat dikatakan tidak berhasil dalam mengajar. Indikator dari ketidakberhasilan guru adalah prestasi siswa yang rendah, tidak sesuai dengan standar atau batas ukuran yang ditentukan. Kegagalan ini bukan hanya ketidakberhasilan guru dalam mengajarkan tugasnya yaitu menguasai materi bidang studi ketika penyampaian saja, akan tetapi ketidaktahuan guru dalam me-manage kelas. Hal ini berakibat pada ketidakefektifan pembelajaran khususnya PAI sehingga kualitas siswa menurun". 2

Untuk meningkatkan keefektifan pembelajaran khususnya bidang studi PAl, ada hal yang perlu diperhatikan oleh seorang guru. Guru hendaknya harus pandai dalam manajemen kelas agar dalam pembelajaran berjalan

${ }^{2}$ Ibid., hlm. 190-191.

152| PENINGKATAN EFEKTIVITAS PEMBELAJARAN PENDIDIKAN AGAMA ISLAM (PAI) MELALUI MANAJEMEN KELAS 
secara efektif dan optimal. Adapun ruang lingkup dari manajemen kelas terdiri atas kegiatan akademik berupa perencanaan, pelaksanaan dan penilaian pembelajaran, serta berupa kegiatan administratif yang mencakup kegiatan prosedural dan organisasional seperti, penataan ruangan, pengelompokan siswa dalam pembagian tugas, penegakan disiplin kelas, pengadaan tes, pengorganisasian kelas, pencatatan kelas dan pelaporan. ${ }^{3}$

Dengan manajemen kelas ini maka siswa akan termotivasi dalam pembelajaran terutama pada manajemen suasana kelas yang pada khususnya merupakan modal penting bagi jernihnya pikiran dalam mengikuti pelajaran, ${ }^{4}$ sehingga anak akan merasa nyaman dan antusias. Dengan pembelajaran Pendidikan Agama Islam yang kondusif dan suasana yang cenderung rekreatif, maka akan dapat mendorong siswa untuk mengembangkan potensi kreatifitasnya.

Belajar merupakan suatu proses yang ditandai dengan adanya perubahan pada diri seseorang. Sedangkan pembelajaran merupakan sebagian dari proses belajar dapat ditujukan dalam berbagai bentuk, seperti perubahan pengetahuan, pemahaman sikap, dan tingkah laku, ketrampilan, kecakapan, kebiasaaan serta merupakan beberapa aspek lain yang ada pada individu yang belajar.

Tingkah laku sebagai proses dari hasil belajar dipengaruhi oleh beberapa faktor baik internal maupun eksternal. Adapun faktor internal adalah kemampuan yang dimiliki oleh siswa, yaitu minat dan perhatiannya, kebiasaan usaha dan motivasi serta beberapa faktor lainnya. Sedangkan faktor eksternal dalam pendidikan dan pengajaran dapat dibedakan menjadi tiga lingkungan yaitu lingkungan keluarga, sekolah dan masyarakat. Semua itu sangat mempengaruhi pembelajaran terutama di lingkungan sekolah yaitu tentang manajemen kelas yang akan berpengaruh pada proses pembelajaran siswa dalam meningkatkan efektifitas belajar yang lebih optimal. ${ }^{5}$

Perkembangan ilmu pengetahuan dan teknologi semakin mendorong upaya-upaya pembaharuan dalam dunia pendidikan. Berbagai upaya untuk mencapai tujuan pendidikan Indonesia dewasa ini juga terus berlangsung. Adapun salah satu upaya yang diprioritaskan untuk mencapainya adalah peningkatan mutu pendidikan. Untuk peningkatan mutu pendidikan ini seluruh komponen pendidikan juga perlu ditingkatkan. Selain itu juga dengan adanya otonomi daerah maka muncul sebuah keputusan baru dalam sektor

${ }^{3}$ www.pikiran-rakyat.com/cetak/0803/14/03x2.htm.

${ }^{4}$ Suharsimi Arikunto, Op.cit., hlm. 207

${ }^{5}$ Nana Sudjana, CBSA Dalam Proses Belajar Mengajar (Bandung: Sinar Baru, 1989), hlm. 54. 
pendidikan terkait dengan upaya peningkatan mutu pendidikan sekolah yaitu Manajemen Berbasis Sekolah. Dalam mengimplementasikan MBS secara efektif dan efisien, para guru harus berkreasi dalam meningkatkan manajemen kelas dengan tepat agar pembelajaran berlangsung secara maksimal, efisien dan efektif. ${ }^{6}$ Karena kelas merupakan media pertemuan segala komponen pendidikan serta ujung tombak dan juga basis pendidikan.

Kehidupan dan peradaban manusia di awal millennium ketiga ini telah banyak mengalami perubahan. Dalam merespon fenomena itu, manusia berpacu mengembangkan pendidikan diberbagai bidang ilmu. Namun bersamaan dengan itu munculah krisis multi dimensi, krisis politik, ekonomi, sosial, hukum, golongan dan ras. Akibatnya peran serta efektifitas pendidikan Agama Islam di sekolah sebagai pemberi nilai spiritual terhadap kesejahteraan masyarakat mulai dipertanyakan. Dengan asumsi jika pendidikan agama dilakukan dengan baik, maka kehidupan masyarakat akan jauh lebih baik.

Melihat fenomena tersebut, seolah-olah Pendidikan Agama Islam dianggap kurang memberikan kontribusi yang menuju arah itu tanpa melihat problem sebenarnya pada Pendidikan Agama Islam. Akan tetapi setelah ditelusuri ternyata adalah kurangnya seorang guru dalam memerankan manajemen kelas. Dan memang tidak adil jika harus menimpakan tanggung jawab atas munculnya kesenjangan antara harapan dan kenyataan itu kepada Pendidikan Agama Islam. Sebab pendidikan agama di sekolah bukanlah satusatunya faktor yang menentukan dalam pembentukan watak dan kepribadian siswa. Apalagi dalam pelaksanaan Pendidikan Agama Islam tersebut masih terdapat beberapa kelemahan yang mendorong dilakukannya penyempurnaan yang konsisten. Kelemahan lain, materi Pendidikan Agama Islam, termasuk materi akhlaq yang lebih terfokus pada pengayaan pengetahuan (kognitif) dan minim dalam pembentukan sikap (afektif) serta pembiasaan (psikomotorik).

\section{B. PEMBAHASAN}

1. Konsep dan Pengertian Manajemen Kelas.

Menurut Pidarta seperti yang telah dikutip oleh Saiful Bakhri, mengatakan bahwa "Manajemen kelas adalah proses seleksi dan penggunaan alat-alat yang tepat terhadap problem kelas. Ini berarti guru

${ }^{6}$ Mulyasa, Manajemen Berbasis Sekolah Konsep Strategi dan Implementasi (Bandung: Remaja Rosydakarya, 2002), hlm.57

154| PENINGKATAN EFEKTIVITAS PEMBELAJARAN PENDIDIKAN AGAMA ISLAM (PAI) MELALUI MANAJEMEN KELAS 
bertugas menciptakan, memperbaiki dan memelihara sistem/ organisasi kelas, sehingga anak didik dapat memanfaatkan kemampuannya, bakatnya dan energinya pada beberapa tugas individualnya". ${ }^{7}$

Menurut Sudirman, bahwa "Manajemen kelas merupakan upaya dalam mendayagunakan potensi kelas, karena itu kelas mempunyai peranan dan fungsi tertentu dalam menunjang keberhasilan proses interaksi edukatif, maka agar memberikan dorongan dan rangsangan terhadap anak didik untuk belajar, kelas harus dikelola sebaik-baiknya oleh guru". ${ }^{8}$

Dari kedua pendapat tersebut dapat ditarik garis tengah, bahwa manajemen kelas suatu upaya memberdayakan potensi kelas yang ada seoptimal mungkin untuk mendukung proses interaksi edukatif dalam mencapai tujuan pembelajaran.

Sedangkan Menurut Johanna Kasin Lemlech, (Cece Wijaya:1994) manajemen kelas adalah suatu usaha yang dilakukan oleh seorang guru dalam menata kehidupan yang ada di kelas mulai dari perencanaan kurikulumnya, penataan prosedur dan sumber belajarnya, pengaturan lingkungannya untuk memaksimalkan efisiensi dan memantau kemajuan siswa serta mengantisipasi beberapa masalah yang kemungkinan timbul di kelas tersebut. ${ }^{9}$

Menurut Oemar Hamalik, seperti yang telah dikutip oleh Made Pidarta definisi manajemen kelas ada dua paham, yaitu paham lama dan paham baru. Paham lama mengatakan manajemen kelas hanya merupakan sebuah pertahanan kelas dengan tujuan mewujudkan ketertiban kelas. Dan paham baru mengatakan bahwa manajemen kelas merupakan suatu proses seleksi dalam menggunakan alat-alat yang tepat terhadap beberapa problema dalam perwujudan situasi kelas yang efisien. ${ }^{10}$

Kelas sebagai lingkungan belajar siswa yang merupakan aspek dari lingkungan yang harus diorganisasikan dan dikelola secara sistematis. Lingkungan ini harus diawasi, agar kegiatan belajar mengajar bisa terarah dan menuju pada sasaran yang dikehendaki. Pengawasan terhadap lingkungan belajar mengajar itu juga dimaksudkan untuk mendorongnya menjadi lingkungan yang baik. Karakteristik lingkungan yang baik itu, diantaranya kelas memiliki sifat merangsang dan menantang siswa untuk selalu belajar memberi rasa aman dan kepuasan dalam tujuan belajar.

7 Saiful Bakhri Djamarah, Guru dan Anak Didik Dalam Interaksi Edukatif (Jakarta: Rineka Cipta, 2000), hlm. 172-173

${ }^{8}$ Ibid.

${ }^{9}$ Cece Wijaya dan Tabrani Rusyan, Op.cit., hlm. 113

${ }^{10}$ Made pidarta, Pengelolaan Kelas (Surabaya: Usaha Nasional,), hlm. 11 
Dengan demikian, berarti bahwa kelas itu mempunyai peran dan fungsi tertentu yang nyata-nyata dapat menopang keberhasilan proses belajar mengajar. Sehingga agar dapat memberikan rangsangan terhadap siswa dalam situasi dan kondisi belajar, maka kelas perlu dikelola sebaik mungkin. Hubungan baik antara guru dan siswa, siswa yang satu dengan yang lainnya dipandang sebagai indikasi keberhasilan manajemen kelas. Dari sini tepat dikatakan bahwa manajemen kelas secara dinamis merupakan penentu perwujudan proses pembelajaran yang efektif. Dan untuk menciptakan suasana yang dapat menumbuhkan gairah belajar, meningkatkan prestasi belajar siswa, serta lebih memungkinkan guru memberikan bimbingan dan bantuan terhadap siswa dalam belajar, maka diperlukan manajemen kelas yang baik dan memadai. ${ }^{11}$ Manajemen kelas yang asal-asalan jelas nyata bisa menampakkan proses pembelajaran yang rusak.

\section{Tujuan dan Fungsi Manajemen Kelas.}

Secara umum yang menjadi tujuan pengelolaan kelas dalam pandangan Sudirman, adalah penyediaan fasilitas bagi bermacam-macam kegiatan pembelajaran siswa dalam lingkungan sosial, emosional dan intelektual dalam kelas. Fasilitas yang disediakan itu memungkinkan siswa belajar dan bekerja, terciptanya suasana sosial yang memberikan kepuasan, suasana disiplin, perkembangan intelektual, emosional dan sikap apresiasi para siswa.

Secara khusus, yang menjadi tujuan pengelolaan kelas dalam pandangan Usman adalah mengembangkan kemampuan siswa dalam menggunakan alat-alat belajar, menyediakan kondisi-kondisi yang memungkinkan siswa bekerja dan belajar serta membantu siswa untuk memperoleh hasil yang diharapkan. ${ }^{12}$

Pengelolaan kelas dimaksudkan untuk menciptakan kondisi dalam kelompok kelas yang berupa lingkungan kelas yang baik, yang memungkinkan siswa berbuat sesuai dengan kemampuannya. Kemudian dengan pengelolaan kelas produknya harus sesuai dengan tujuan-tujuan yang hendak dicapai. Tujuan pengelolaan kelas pada hakikatnya telah terkandung dalam tujuan pendidikan.

Adapun menurut Udin Saifuddin tujuan manajemen kelas meliputi antara lain menfasilitasi kegiatan belajar mengajar secara maksimal, untuk mencapai tujuan pembelajaran memberikan kemudahan dalam mendukung

${ }^{11}$ Cony Semiawan, Pendekatan Ketrampilan Proses, Bagaimana Mengaktifkan Siswa Dalam Belajar (Jakarta: Grasindo, 1992), hlm. 64.

${ }^{12}$ Ibid., hlm. 284. 
sumber-sumber belajar serta membangkitkan gairah (ghiroh) belajar siswa. Selain itu juga mengembangkan disiplin belajar siswa sesuai dengan kebutuhan dan perkembangannya. ${ }^{13}$

\section{Ruang Lingkup dan Aspek-aspek Manajemen Kelas.}

Menurut Udin Saifuddin, bahwa ruang lingkup manajemen kelas terdiri atas kegiatan akademik berupa perencanaan pembelajaran, pelaksanaan pembelajaran, dan penilaian pembelajaran. Selain itu juga berupa kegiatan administratif yang mencakup kegiatan procedural dan organisasional, seperti penataan ruangan, pengelompokan siswa dan tugas, penegakan disiplin kelas, pengadaan tes dan menilainya, iklim kelas yang favourable, pengorganisasian kelas, penataan kelas dan pelaporan. ${ }^{14}$ Mengenai aspekaspek manajemen kelas ini, maka dibedakan menjadi dua:

a) Kegiatan Administratif Manajemen.

Kegiatan administratif pendidikan tidak terlepas dari proses manajemen. Administratif dalam pandangan Shulhan adalah seluruh kegiatan dalam setiap usaha kerjasama sekelompok orang untuk mencapai tujuan bersama. Berkaitan dengan hal ini Nawawi berpandangan bahwa "...sebuah kelas pada dasarnya merupakan suatu unit kerja yang di dalamnya bekerja sejumlah orang untuk mencapai tujuan". ${ }^{15}$

Dengan demikian, dalam suatu kelas harus ada upaya untuk menciptakan kondisi kelas yang diliputi dorongan untuk aktif secara terarah yang dikembangkan melalui kreatifitas dan inisiatif siswa dalam sebuah kelompok. Oleh sebab itu, dalam mengelola suatu kelas, guru atau wali kelas tentu menjalani langkah-langkah manajemen administrative yang meliputi perencanaan, pengorganisasian, pengarahan, pengkoordinasian, pengkomunikasian dan pengontrolan. Adapun penjelasannya adalah sebagai berikut:

b) Kegiatan Operatif Manajemen.

Agar seluruh program kelas dapat direalisasikan secara efektif mencapai tujuan, maka kegiatan administrative manajemen di atas harus ditunjang oleh kegiatan operatif manajemen berikut ini: tata usaha, perbekalan kelas, keuangan kelas, personal kelas, kehumasan,

\section{Masalah dan Kunci Keberhasilan Manajemen Kelas.}

Tingkah laku anak didik bervariasi. Dan variasi perilaku anak merupakan permasalahan bagi guru dalam upaya manajemen kelas. Menurut

\footnotetext{
${ }^{13}$ www.pikiran-rakyat.com/cetak/0803/14/03x2.htm.

${ }^{14}$ Ibid.

${ }^{15}$ Mujamil Qomar, Op.cit., hlm. 285.
} 
Made Pidarta, masalah-masalah manajemen kelas berhubungan dengan perilaku anak didik adalah:

a. Kurang kesatuan, dengan adanya kelompok-kelompok dan pertentangan jenis kelamin.

b. Tidak ada standar perilaku dalam bekerja kelompok, misalnya ribut, bercakap-cakap dan sebagainya.

c. Reaksi negatif terhadap anggota kelompok, misalnya ribut bermusuhan, mengucilkan, dan merendahkan kelompok bodoh.

d. Kelas mentoleransi kekeliruan-kekeliruan temannya, menerima dan mendorong perilaku anak didik yang keliru.

e. Mudah mereaksi ke hal-hal negatif/ terganggu, misalnya bila didatangi monitor, tamu-tamu, iklim yang berubah.

f. Moral rendah, permusuhan, agresif, misalnya dalam lembaga yang alatalat belajarnya kurang.

g. Tidak mampu menyesuaikan dengan lingkungan yang berubah seperti tugas-tugas tambahan, anggota kelas yang baru, situasi baru dan sebagainya. $^{16}$

Mengenai masalah manajemen kelas dapat dikelompokkan menjadi dua kategori yaitu masalah individual dan masalah kelompok. Meskipun seringkali perbedaan antara kedua kelompok itu hanya merupakan perbedaan tekanan saja. Tindakan manajemen kelas seorang guru akan efektif apabila ia dapat mengidentifikasi dengan tepat hakikat masalah yang sedang dihadapi, sehingga pada gilirannya ia dapat memilih strategi penanggulangannya yang tepat pula.

Lois V. Johnson dan Mary A. Bany mengemukakan enam kategori masalah kelompok dalam pengelolaan kelas. Masalah-masalah yang dimaksud adalah sebagai berikut:

a. Kelas kurang kohesif, misalnya perbedaan jenis kelamin, suku dan tingkatan sosio-ekonomi.

b. Kelas mereaksi negatif terhadap salah seorang anggotanya. Misalnya mengejek anggota kelas yang dalam pengajaran seni suara menyanyi dengan suara sambung.

c. "Membesarkan" hati anggota kelas yang justru melanggar norma kelompok, misalnya pemberian semangat kepada badut kelas.

d. Kelompok cenderung mudah dialihkan perhatiannya dari tugas yang tengah dikerjakan.

${ }^{16}$ Syaiful Bakhri Djamarah, Op.cit., hlm. 173.

158| PENINGKATAN EFEKTIVITAS PEMBELAJARAN PENDIDIKAN AGAMA ISLAM (PAI) MELALUI MANAJEMEN KELAS 
e. Semangat kerja rendah. Misalnya semacam aksi protes kepada guru karena menganggap tugas yang diberikan kurang adil.

f. Kelas kurang mampu menyesuaikan diri dengan keadaan baru. Misalnya gangguan jadwal antar guru kelas terpaksa diganti sementara oleh guru lain. ${ }^{17}$

Mengenai kunci keberhasilan manajemen kelas, guru dan wali kelas yang merupakan pengemban amanat kepala sekolah perlu memperhatikan kunci keberhasilan supaya dapat mengatasi dan menghadapi ancaman, gangguan serta hambatan dan tantangan ketika merealisasikan tugas-tugas yang relevan dengan maksud perealisasian amanat.

\section{Pendekatan Manajemen Kelas.}

Ada beberapa pendekatan yang dijadikan sebagai alternatif pertimbangan dalam usaha menciptakan disiplin kelas yang efektif, antara lain:

a. Pendekatan Manajerial.

Pendekatan ini dilihat dari sudut pandangan manajemen yang berintikan konsepsi-konsepsi tentang kepemimpinan. Dalam pendekatan ini dapat dibedakan: (1) Kontrol otoriter, dalam menegakkan disiplin kelas guru harus bersikap keras, kalu perlu dengan hukuman-hukuman yang berat. (2) Kebebasan liberal, menurut konsep ini siswa harus diberi kebebasan sepenuhnya untuk melakukan kegiatan apa saja sesuai dengan tingkat perkembangannya. (3) Kebebasan terbimbing, konsep ini merupakan perpaduan diantara kontrol otoriter dan kebebasan liberal. Dari sini siswa diberi kebebasan untuk melakukan aktivitas, namun terbimbing atau terkontrol. Disiplin kelas yang baik menurut konsep ini lebih ditekankan kepada kesadaran dan pengendalian diri sendiri. ${ }^{18}$

b. Pendekatan psikologis.

Terdapat beberapa pendekatan yang didasarkan atas studi psikologi yang dapat dimanfaatkan oleh guru dalam membina disiplin kelas kepada siswanya. Pendekatan yang dimaksud antara lain: (1) Pendekatan Modifikasi Tingkah laku (Behavior-Modification Approach). (2) Pendekatan iklim sosioemosional (Sosio-Emotional-Climate Approach). (3) Pendekatan proses hlm. 126.

${ }^{17}$ Ahmad Rohani, Pengelolaan Pengajaran (Jakarta: PT. Rineka Cipta, 2004),

${ }^{18}$ Sudirman dkk, Op.cit., hlm. 328. 
kelompok (Group-Processess Approach). (4) Pendekatan eklektik (Eclectic Approach).

\section{Hambatan-hambatan Manajemen Kelas.}

Dalam manajemen kelas akan ditemui berbagai faktor penghambat. Hambatan tersebut bisa datang dari guru sendiri, peserta didik, lingkungan keluarga ataupun karena faktor fasilitas. Dan dari uraian diatas tampaklah bahwa kewenangan penanganan masalah pengelolaan dapat diklasifikasikan menjadi tiga kategori, yaitu: ${ }^{19}$

a. Masalah yang ada dalam wewenang guru.

Ada sejumlah masalah pengelolaan kelas yang ada dalam ruang lingkup wewenang seorang guru bidang studi untuk mengatasinya. Hal ini berarti bahwa seorang guru bidang studi yang sedang mengelola proses pembelajaran dituntut untuk dapat menciptakan, memperhatikan dan mengembalikan iklim belajar kepada kondisi belajar mengajar yang menguntungkan kalau ada gangguan sehingga peserta didik berkesempatan untuk mengambil manfaat yang optimal dari kegiatan belajar yang dilakukannya.

b. Masalah yang ada dalam wewenang sekolah sebagai lembaga pendidikan.

Dalam kenyataan sehari-hari di kelas, akan ditemukan masalah pengelolaan yang lingkup wewenang untuk mengatasinya berada di luar jangkauan guru bidang studi. Masalah ini harus diatasi oleh sekolah sebagai suatu lembaga pendidikan. Bahkan mungkin juga ada masalah pengelolaan yang tidak bisa hanya diatasi oleh satu lembaga pendidikan akan tetapi menuntut penanganan bersama antarasekolah.

Masalah-masalah yang ada dibawah wewenang sekolah antara lain pembagian ruangan yang adil untuk setiap tingkat atau jurusan, pengaturan upacara bendera pada setiap hari senin dan bila pada hari itu turun hujan lebat, menegur peserta didik yang selalu terlambat pada saat apel bendera, mengingatkan peserta didik yang tidak mau memakai seragam sekolah, menasehati peserta didik yang rambutnya gondrong, memberi peringatan keras kepada peserta didik yang merokok di kelas atau sekolah dan suka minum-minuman keras, sampai kepada mendamaikan peserta didik jika terjadi perselisihan antarsekolah. ${ }^{20}$

c. Masalah yang ada di luar wewenang guru bidang studi dan sekolah.

${ }^{19}$ Ahmad Rohani, Op. cit., hlm. 155.

${ }^{20}$ Cece Wijaya dan Tabrani Rusyan, Op.cit., hlm. 135. 
Dalam mengatasi masalah semacam ini mungkin yang harus terlibat adalah orang tua, lembaga-lembaga yang ada dalam masyarakat seperti karang taruna, bahkan para pengusaha dan lembaga pemerintahan setempat.

Selain masalah diatas ada juga beberapa faktor yang menjadi penghambat dalam manajemen kelas adalah: (1) Faktor guru, faktor penghambat yang datang dari sini berupa hal-hal, seperti: tipe kepemimpinan guru yang otoriter, format belajar mengajar yang tidak bervariasi (monoton), kepribadian guru yang tidak baik, pengetahuan guru yang kurang, serta pemahaman guru tentang peserta didik yang kurang. ${ }^{21}$ (2) Faktor peserta didik. Kekurangsadaran peserta didik dalam memenuhi tugas dan haknya sebagai anggota kelas atau suatu sekolah akan menjadi masalah dalam pengelolaan kelas. (3) Faktor keluarga. Tingkah laku peserta didik di dalam kelas merupakan pencerminan keadaan keluarganya. Sikap otoriter orang tua akan tercermin dari tingkah laku peserta didik yang agresif atau apatis. Di dalam kelas sering ditemukan ada peserta didik penganggu dan pembuat ribut, mereka itu biasanya dari keluarga yang broken-home. (4) Faktor fasilitas. Faktor ini meliputi: jumlah peserta didik dalam kelas yang terlalu banyak dan tidak seimbang dengan ukuran kelas, besar dan kecilnya ruangan tidak disesuaikan dengan jumlah peserta didiknya, ketersediaan alat yang tidak sesuai dengan jumlah peserta didik yang membutuhkannya. ${ }^{22}$

\section{Manajemen Kelas Dalam Efektifitas Pembelajaran.}

Pendidikan merupakan proses tindakan bimbingan dan pertolongan untuk membantu pertumbuhan dan perkembangan kepribadian peserta didik. Pendidikan mengusahakan pembinaan pribadi manusia sampai pada tujuan akhirnya yaitu kebahagiaan dan sekaligus berguna bagi kepentingan masyarakat. Maka kegiatan pendidikan yang benar adalah pembinaan kepribadian manusia untuk mampu membina hubungan yang harmonis dengan Tuhan dan diri sendiri, serta sekaligus untuk kepentingan masyarakat, perilaku hubungan dengan keluarga, masyarakat dan alam sekitar.

Oleh karena itu, dalam proses pembelajaran kelas perlu dikelola sedemikian rupa sehingga membantu pertumbuhan dan perkembangan kepribadian peserta didik. Pengelolaan kelas tidak sekedar bagaimana mengatur ruang kelas dengan segala sarana dan prasarananya, tetapi menyangkut bagaimana interaksi dan pribadi-pribadi di dalamnya. Pengelolaan kelas lebih ditekankan bagaimana pribadi-pribadi dalam kelas dapat menjadi suatu komunitas yang penuh persaudaraan dan kekeluargaan.

${ }^{21}$ Ahmad Rohani, Op.cit., hlm. 156.

${ }^{22}$ Ibid., hlm. 159. 
Komunitas yang demikian akan mengembangkan kepribadian baik pendidik maupun peserta didiknya. Dari sini, maka peserta didik di kelas tidak hanya belajar aspek pengetahuan akan tetapi juga aspek afektif dan sosialitasnya. ${ }^{23}$

Pengelolaan kelas merupakan ketrampilan guru untuk menciptakan iklim pembelajaran yang kondusif dan mengendalikannya jika terjadi gangguan dalam pembelajaran. Beberapa prinsip yang harus diperhatikan dalam pengelolaan kelas adalah (1) kehangatan dan keantusiasan, (2) tantangan, (3) bervariasi, (4) luwes, (5) penekanan pada hal-hal positif, (6) penanaman disiplin diri.

Ketrampilan mengelola kelas memiliki komponen sebagai berikut: ${ }^{24}$

a. Penciptaan dan pemeliharaan iklim pembelajaran yang optimal.

1) Menunjukkan sikap tanggap dengan cara: memandang secara seksama, mendekati, memberikan pernyataan dan memberi reaksi terhadap gangguan di kelas.

2) Membagi reaksi secara visual dan verbal.

3) Memusatkan perhatian kelompok dengan cara menyiapkan peserta didik terhadap gangguan di kelas.

4) Memberi petunjuk dan teguran secara jelas dan bijaksana.

b. Ketrampilan yang berhubungan dengan pengendalian kondisi belajar yang optimal, dengan cara:

1) Modifikasi perilaku:

a) Mengajarkan perilaku baru dengan contoh dan pembiasaan.

b) Meningkatkan perilaku yang baik melalui penguatan.

c) Mengurangi perilaku buruk dengan hukuman.

2) Pengelolaan kelompok dengan cara (1) peningkatan kerjasama dan ketertiban, (2) menangani konflik dan memperkecil masalah yang timbul.

3) Menemukan dan mengatasi perilaku yang menimbulkan masalah:

a) Pengabaian yang direncanakan.

b) Campur tangan dengan isyarat.

c) Mengawasi secara ketat.

d) Mengakui perasaan negatif peserta didik.

e) Mendorong peserta didik untuk mengungkapkan perasaannya

${ }^{23}$ Theo Riyanto, Pembelajaran Sebagai Suatu Bimbingan Pribadi (Jakarta: PT. Gramedia Widiasarana Indonesia, 2002), hlm. 46.

${ }^{24}$ Mulyasa, Op.cit., hlm. 91. 
f) Menghilangkan ketegangan dengan belajar dan mengekang secara fisik.

Ada asumsi bahwa manajemen kelas yang baik merupakan hasil sadar atas peranan guru untuk mengintegrasikan manajemen interaksi (belajar mengajar) dengan perencanaan interaksi pengajaran. Perpaduan ini seringkali menghasilkan persoalan dalam masalah disiplin. Interaksi belajar mengajar dan manajemen hakikatnya tidak terpisah, tetapi lebih merupakan dua komponen utama yang harus dibangun satu dengan lainnya jika menginginkan tercapainya kelas yang harmonis.

Ketrampilan guru yang efektif akan mengawasi perilaku murid dengan waktu yang baik, dengan memberikan pertanyaan yang baik, atau jenis pengalaman pembelajaran. Pengawasan itu justru bisa efektif sebagai tindakan manajemen kelas secara langsung. Meskipun pengajaran dan manajemen dilakukan berbeda, keduanya saling melengkapi dan berinteraksi dalam cara-cara yang produktif. Guru menyusun perencanaan pengajaran. Selanjutnya memimpin dalam proses pengajaran, memotivasi dalam belajar, dan selanjutnya mengawasi atau mengevaluasi hasil belajar. Semua itu adalah tindakan manajemen kelas yang dipadukan untuk mencapai efektifitas pembelajaran. ${ }^{25}$

\section{Standar Efektifitas Pembelajaran PAI.}

Guru memiliki peran yang sangat penting dalam menentukan kuantitas dan kualitas pengajaran yang dilaksanakannya khususnya dalam pembelajaran PAI. Guru berperan sebagai pengelola proses pembelajaran, bertindak selaku fasilitator yang berusaha menciptakan kondisi pembelajaran yang efektif sehingga memungkinkan proses pembelajaran, mengembangkan bahan pengajaran dengan baik dan meningkatkan kemampuan siswa untuk menyimak pelajaran dan menguasai tujuan-tujuan pendidikan yang harus mereka capai.

Standar efektifitas pembelajaran PAI antara lain:

a.

Dapat melibatkan siswa secara aktif.

Menurut William Burton mengajar adalah membimbing kegiatan belajar siswa sehingga ia mau belajar. ${ }^{26}$ Dengan demikian, aktivitas murid sangat diperlukan dalam proses pembelajaran, sehingga muridlah yang seharusnya banyak aktif sebab murid sebagai subyek didik adalah yang merencanakan dan ia sendiri yang melaksanakan belajar.

${ }^{25}$ Syafaruddin, Manajemen Mutu Terpadu dalam Pendidikan, Konsep, Strategi dan Aplikasi (Jakarta: Grasindo, 2002), hlm. 103.

26 Moh. Uzer Usman, Menjadi Guru Profesional (Bandung: PT. Remaja Rosdakarya Offset, 1995), hlm. 16. 
b. Dapat menarik minat dan perhatian siswa.

Kondisi belajar yang efektif adalah adanya minat dan perhatian siswa dalam belajar. Minat merupakan suatu sifat yang relatif menetap pada diri seseorang. Minat ini besar sekali pengaruhnya terhadap belajar sebab dengan minat seseorang akan melakukan sesuatu yang diminatinya. Keterlibatan siswa dalam belajar erat kaitannya dengan sifat-sifat murid, baik yang bersifat kognitif, afektif maupun psikomotorik. Sehingga hal itu akan menjadikan pembelajaran PAI berjalan secara efektif.

c. Dapat membangkitkan motivasi siswa.

Motivasi adalah suatu proses untuk menggiatkan motif-motif menjadi perbuatan atau tingkah laku untuk memenuhi kebutuhan dan mencapai tujuan, atau kesadaran dan kesiapan dalam diri individu yang mendorong tingkah lakunya untuk berbuat sesuatu dalam mencapai tujuan tertentu. Pembelajaran PAl bisa dikatakn efektif apabila dapat membangkitkan motivasi siswa yang sedang belajar.

d. Prinsip individualitas.

Pembelajaran PAI akan berjalan efektif kalau guru selalu harus memperhatikan keragaman karakteristik setiap siswa karena dengan begitu maka siswa akan merasakan perhatiannya dan pembelajaran juga akan terlaksana dengan maksimal.

e. Peragaan dalam pengajaran.

Belajar yang efektif harus mulai dengan pengalaman langsung atau pengalaman konkrit dan menuju kepada pengalaman yang lebih abstrak. Dan apabila pembelajaran dilaksanakan dengan melaksanakan peragaan yang sesuai maka akan dapat membantu siswa dalam pembelajaran. ${ }^{27}$

f. Pembelajaran yang dapat menjadikan siswa antusias.

Keantusiasan siswa dalam pembelajaran khususnya PAI akan berpengaruh pada efektifitas proses pembelajaran yang dilakukannya.

\section{PENUTUP}

Manajemen kelas yang diterapkan dalam meningkatkan efektifitas pembelajaran meliputi beberapa hal diantaranya: perencanaan pembelajaran, pengorganisasian pembelajaran, pengkomunikasian, pemilihan metode, penggunaan media, disiplin kelas, konflik kelas, evaluasi pembelajaran, penataan ruangan. Adapun pelaksanaan peningkatkan efektifitas pembelajaran PAI melalui manajemen kelas tentunya banyak terdapat hambatan-hambatan yang dihadapi diantaranya; kurangnya

${ }^{27}$ Ibid., hlm. 24.

164| PENINGKATAN EFEKTIVITAS PEMBELAJARAN PENDIDIKAN AGAMA ISLAM (PAI) MELALUI MANAJEMEN KELAS 
kesadaran dan tanggung jawab siswa dalam melakukan efektifitas pembelajaran PAI, kurangnya fasilitas dan media pembelajaran PAI yang ada di sekolah, keadaan ekonomi orang tua yang kurang cukup, lingkungan siswa yang keras serta keadaan keluarga yang broken home. Dari hambatanhambatan tersebut tentunya perlu dilaksanakan usaha-usaha dalam memecahkan problem-problem manajemen kelas terkait dengan pembelajaran PAI yaitu: mempersiapkan tugas administratif, memberi motivasi kepada siswa, membuat modul sesuai dengan materi, mengatasi setiap permasalahan siswa, memilih metode, membentukan kelompok diskusi, meningkatkan kedisiplinan siswa.

\section{DAFTAR PUSTAKA}

Arikunto, Suharsimi. 1990. Manajemen Pengajaran Secara Manusiawi. Jakarta: PT. Rineka Cipta.

Jakarta: PT.Rineka Cipta.

1990. Manajemen Penelitian. Jakarta: Rineka Cipta

Djamarah, Saiful Bakhri. 2000. Guru dan Anak Didik Dalam Interaksi Edukatif, Jakarta: Rineka Cipta.

Hadi, Sutrisno. 1989. Metodologi Research I. Yogyakarta: PT. Andi Offset cet. XXIII

Majid, Abdul dan Dian Andayani. 2004. Pendidikan Agama Islam Berbasis Kompetensi, Konsep dan Implementasi Kurikulum 200. Bandung: Remaja Rosdakarya Offset.

Moleong, Lexy. 2002. Metode Penelitian Kualitatif. Bandung: PT. Remaja Rosdakarya Offset.

Muhaimin. 2002. Paradigma Pendidikan Islam, Upaya Mengefektifkan PAl di Sekolah. Bandung: Remaja Rosdakarya.

Mulyana, Dedy. 2001. Metodologi Penelitian Kualitatif: Paradigma Baru IImu Komunikasi dan Ilmu Sosial lainnya. Bandung: Remaja Rosydakarya.

Mulyasa. 2005. Menjadi Guru Profesional, Menciptakan Pembelajaran Kreatif dan Menyenangkan. Bandung: Remaja Rosdakarya.

----------- 2004. Manajemen Berbasis Sekolah Konsep Strategi dan Implementasi. Bandung: Remaja Rosydakarya.

Nasution. 1998. Metode Penelitian Naturalistik-Kualitatif. Bandung: TARSITO.

Nawawi, Hadari. 1989. Organisasi Sekolah dan Pengelolaan Kelas Sebagai Lembaga Pendidikan. Bandung: Remaja Rosdakarya.

Pidarta, Made. Pengelolaan Kelas. Surabaya: Usaha Nasional

Pius A.P., Dahlan Barry. 1995. Kamus Ilmiah Populer. Surabaya: Arkola. 
Qomar, Mujamil. 2002. Meniti Jalan Pendidikan Islam. Yogyakarta: Pustaka Pelajar Offset.

Riyanto, Theo. 2002. Pembelajaran Sebagai Suatu Bimbingan Pribadi, Jakarta: PT. Gramedia Widiasarana Indonesia.

Rohani, Ahmad. 2004. Pengelolaan Pengajaran. Jakarta: PT. Rineka Cipta. Cet II.

Rohani, Ahmad dan Abu Ahmadi. 1991. Pedoman Penyelenggaraan Administrasi Pendidikan Sekolah. Jakarta: Bumi Akasara.

UU RI No. 20 Tahun 2003 Tentang Sistem Pendidikan Nasional. Bandung: Citra Umbara.

Semiawan, Cony, 1992. Pendekatan Ketrampilan Proses, Bagaimana Mengaktifkan Siswa Dalam Belajar. Jakarta: Grasindo.

Sudirman. 1991. Ilmu Pendidikan:Kurikulum, Program pengajaran, Efek Intruksional dan pengiring, CBSA, Metode mengajar, Media pendidikan, Pengelolaan kelas dan Evaluasi hasil belajar. Bandung: Remaja Rosdakarya.

Sudjana, Nana. 1989. CBSA Dalam Proses Belajar Mengajar. Bandung: Sinar Baru.

Sugiyono. 2005. Memahami Penelitian Kualitatif. Bandung: CV. Alfabeta.

Sukardi. 2003. Metodologi Penelitian Pendidikan:Kompetensi dan Praktiknya. Jakarta: PT. Bumi Aksara.

Syafaruddin. 2002. Manajemen Mutu Terpadu Dalam Pendidikan, Konsep Strategi dan Aplikasi. Jakarta: Grasindo.

Usman, Mohammad Uzer. 1995. Menjadi Guru Profesional. Bandung: PT. Remaja Rosdakarya Offset.

Wijaya, Cece. 1994. Kemampuan Dasar Guru Dalam Proses Belajar Mengajar. Bandung: Remaja Rosdakarya. cet.IV.

www.pikiran-rakyat.com/cetak/0803/14/03×2.htm.

Zuhairini dan Abdul Ghofir. 2004. Metodologi Pendidikan Agama Islam. Malang: UM Press.

1985. Seni Mengelola Kelas. (di sadur dari Michael Marland "Craft of the Classroom". Semarang: Dahara Prize. 